\title{
The Impact of Neo-Realism in Turkish Intellectual Cinema: The Cases of Yılmaz Güney and Nuri Bilge Ceylan
}

\author{
Aslı Daldal \\ Istanbul Yildiz Technical University, Dept. of Political Science
}

Doi:10.5901/ajis.2013.v2n9p181

\begin{abstract}
Italian neo-realism is the main source of inspiration for many film movements and auteur filmmakers trying to construct a "counter-hegemonic" film language against the dominant cinematic practices. This paper investigates the impact of neo-realism upon the early films of Yılmaz Güney and Nuri Bilge Ceylan. This impact is certainly not monolithic and one dimensional, and like the neorealist movement itself, it is multifaceted and colorful After the coup d'Etat of 1960, social realist filmmakers had already introduced neorealism to Turkish film industry but it took another ten years for a mature and authentic realist political film language to develop. So Yılmaz Güney was among the first filmmakers in Turkey who combined documentary verism and political editing. Some twenty years later, Nuri Bilge Ceylan chose to adopt another "realist" position combining minimalism with a very personal and idiosyncratic film language.
\end{abstract}

\section{Introduction}

Neo-realism is an important film movement developed in the aftermath of the second world war in Italy. Mostly representing the spirit of "resistance" to the Fascist forces, and a wish to rebuild a country devastated by the war, neorealism emerged in an atmosphere of heated intellectual debates. It was also made in unfavorable financial conditions and thus relied mostly on nonprofessional actors and minimalistic stories. It aimed at "going to the streets" in both senses: a) to be politically active and b) to reject the conventions of studio based filmmaking of Cinecitta Era. Neo Realism has also inspired many film filmmakers and film movements around the world. This study aims at comparing two important Turkish filmmakers who applied neo-realistic principles in some of their films. Focusing firstly on Yilmaz Güney's Umut (Hope, 1971), the paper will look at a more politically "engage" application of Neo-realism following in the footsteps of Social Realist movement which took place in the aftermath of 1960 Coup d'Etat in Turkey. Secondly this study will look at a contemporary Turkish filmmaker Nuri Bilge Ceylan who applied a neo-realistic technique in his earlier films (The Town, Clouds of May and Distant). Ceylan, in contrast to Güney, preferred a more minimalistic style and refrained from engaging in bold political statements. He mostly relied on an imagery borrowed from Iranian cinema which, in its turn, shows the naturalistic impact of neo-realism.

\section{Neo-Realism}

Between 1945 and 1953 a total of 822 feature films were made in Italy. Of these films, in the widest sense, 259 were associated with neo-realism. ${ }^{1}$ Although it is less than a third of the total film production, this is still a huge number, given that the remainder were unimportant commercial "genre" films such as comedies, historical dramas or love stories. In this period, all of Italy's respectable filmmakers were in some sense involved in the politics and aesthetics of the new wave reflecting the artistic counterpart of bourgeois progressivism, reformism and the ensuing optimism in the political sphere.

Rome, Open City directed by Rossellini in 1945 is generally considered as the starting point of the movement. There are different views as to the end of neo-realism, but Umberto $D$ of De Sica made in 1951 seems to be the culminating point of the wave. Apart from the changed socio-political conjuncture (the advent of the Marshall Plan and the starting of the Cold War),which made it impossible for the post-war consentual politics to exist in 1951 Umberto $D$ also metaphorically symbolizes the end of the neo-realist "utopia" by the story of the old and abandoned Umberto Domenico. It would of course be wrong to think that the new aesthetic credo abruptly ended in 1951. Many films made until late 1960s 
reflected clear influences of neo-realism. Especially the early films of Fellini (The White Sheik, I Vitelloni..), Antonioni (Story of a Love Affair), and Pasolini (Accatone, Mamma Roma, Hawks and Sparrows..) created discussions as to whether neo-realism should be considered completely dead or still alive. In fact, neo-realism became a powerful aesthetic tradition in Italy and its legacy never totally disappeared from the artistic subconsciousness of the new generation. Combining itself with the rising bourgeois culture and high modernism, neo-realism evolved in the 60s into a beautiful symbiosis between the "humble" and the "personal". But the "genuine" movement itself certainly ended in the early fifties with the dissolution of the post-war élite coalescence and the ensuing revolutionary fervor.

Neo-realist films made between 1945 and 1951 can be thematically categorized into three. One group of films was based on the stories of war and the Resistance. Including the famous trilogy of Rossellini (Rome, Open City, Paisa, Germany Year Zero), Vergano's The Sun Rises Again, Luigi Zampa's Difficult Years, To Live in Peace and Alberto Lattuada's Without Pity, these films generally reflected the tragedies of the war and the unity of the Communist and Catholic partisans. The directors themselves belonged to different political camps and the cinematographic convergence of their themes and perspectives itself reflected a political act of unity. Another group of cinematographers focused on the agricultural problems. The problem of the South ( II Mezzogiorno) still unsolved by the new Government, the absence of land reform and the exploitation of the peasants were the main subjects of the films. These directors often reflected the perspective of the $\mathrm{PCl}$ as in those days, one of the major issues of the left in Italy was the Southern question. Visconti ( La Terra Trema), De Santis ( The Tragic Hunt, Bitter Rice, No Peace Amidst the Olives) together with Lattuada (The Mill on the River), and Pietro Germi (In the Name of Law) made the most important films on the agricultural problems of Italy. The third group of films reflected the urban problems. Unemployment, prostitution and child abuse were the pressing problems of the big cities treated mostly in the films of Vittorio De Sica (Shoeshine, The Bicycle Thieves, Miracle in Milan and Umberto D). These films highly disturbed the Italian bourgeoisie and De Sica was often accused of "rendering bad service to his country."2

"Neo-realism" as an avant-garde style was largely confined to the realm of film, but its "spirit" was shared by many aesthetic trends of the era, parallel to the sociological factors of the immediate post-war period that underlined the formation of such a revolutionary style. Neo-realism was a "state of mind" that any progressive intellectual was supposed to adopt. The basis of this new mentality was a kind of "futurism", a wish to break with the Mussolinian aesthetic credos of the past. According to the four point program outlined in Barbaro's well-known 1943 essay in Cinema, neo-realist films were to:

\footnotetext{
"...1. Get rid of the naïve and mannered clichés which have formed the larger part of Italian films,

2. Abandon those fantastic and grotesque fabrications which exclude human problems and the human point of view,

3. Dispense with historical set-pieces and fictional adaptations,

4. Exclude the rhetoric which pretends that all Italians are inflamed by the same noble sentiments..."3
}

Neo-realist directors often rejected the traditional conventions of the film industry. The use of nonprofessional actors mostly coming from similar walks of life as the protagonists of the films, on-location shooting rather than studio settings, the mise-en scene technique highly praised by André Bazin were the major formal characteristics of this new wave. According to Bazin, the "mise-en-scene" of neo-realist films was a peculiar application of the principles of Orson Welles and Jean Renoir with their "penchant for deep focus photography in sharp contrast to the ideologically inspired montage of Eisenstein." For the neo-realist directors, the "depth of field" gave the audience the chance to choose among the complex elements within a framed image and therefore to go beyond the surface look at the order of things. Bazin emphasized that this movement in principle respected the ontological wholeness of reality by opposing the manipulation of reality in the cutting room. ${ }^{5}$

The choice of nonprofessional actors was more than a simple concern for originality. It reflected a political as well as artistic position that denied the star system and thus the "personality cult" and "heroism" upon which the fascist ideology was based. Says Cesare Zavattini, one of the most prominent theorists of neo-realism:

\footnotetext{
${ }^{2}$ Raymond Bordé and André Bouissy (1960). Le Néo-Realisme Italien: Une Experience de Cinema Social. Lausanne: Cinématheque Suisse.

${ }^{3}$ Ben Lawton (1979). Italian Neorealism: A Mirror Construction of Reality. Film Criticism. 3(2), p. 8.

${ }_{4}^{4}$ Peter Bondanella (1998). Italian Cinema : From Neorealism to the Present. New-York: Frederick Ungar Books, p. 32.

${ }^{5}$ André Bazin (1971)What is Cinema?. University of California Press.
} 
"I am against exceptional persons, heroes. I have always felt an instinctive hate towards them... Heroes create inferiority complexes throughout an audience. The time has come to tell each member of the audience that he is the true protagonist of life. The result would be a constant emphasis on the responsibility and dignity of every human being. This is exactly the ambition of neo-realism: to strenghten everyone; and to give everyone the proper awareness of a human being." 6

The new movement also insisted that the filmic story be based on daily existence. Similar to Siegfried Kracauer's notion of "found story", Zavattini proposed the concept of "cinema of encounter" meaning that the subject on the spot would be preferable to a constructed subject. Very much in the same humanist spirit with Kracauer, Zavattini emphasized that the most important mission of the cinema was to create a dialogue through social awareness and contact. Zavattini proudly declared that (as a script writer) he could make a spectacle out of an ordinary situation:

"For example: let us take two people who are looking for apartment. In the past, the filmmaker would have made it the starting point, using it as a simple and external pretext to base something else on. Today, one can use that simple situation of hunting for an apartment as the entire subject of the film. It must be understood, of course, that this is true only if the situation is always emphasized with all echoes and reverberations which are present in it."

Neo-realism was a rich and complex cultural phenomenon of the post-war reconstruction period. Not surprisingly, it was adopted by many contradictory intellectual circles, each defining it according to its own political and ideological purposes. Thus Marxists emphasized the social and political commitments of neo-realist films. For them neo-realism depended above all on "content". The famous Marxist critic George Sadoul has written, "From 1945 on, Italian neorealism emerged as an essential phenomenon of world cinema; it was no one's offspring; it was created by a people and by a nation in the forward march of history and the clash of social struggles..." 9 It was the first massive experience of a "social cinema". It contributed to the formation of a popular bloc and gave the chance to those formerly deprived of any means of expression, a chance to raise their voice. ${ }^{10}$ Catholics on the other hand, emphasized the "spiritual", "human" aspects of neo-realism. The famous ex-catholic priest Ayfre said that the basis of neo-realism was a dialogue between man and the reality. This reality was never expressed with distance and coldness but always embodied a fraternal curiosity. This dialogue was not possible under constraint. Thus neo-realism was truly a style of "democracy" and was unthinkable in totalitarian systems. ${ }^{11}$ We also know that early Fellini and post 1947 Rossellini opted for religious realism in their works. As for modernists and phenomenologists, neo-realism was basically defined on the basis of "formal" criteria. They often quoted Italo Calvino who said that "the musical score is more important than the libretto."12 This multivocal interpretation of neo-realism is also the basis for its varied forms of adaptation in world cinemas. Some adopted its political emphasis (anti-Hollywood, thus anti-imperialistic premises, anti-fascist thus progressive elements, antibourgeois frameworks), some, on the other hand, preferred to underline its humanistic and minimalistic features.

\section{Social Realism in Turkey}

Neo-realism had a great impact upon the Turkish Cinema. Between 1960 and 1965, within the newly established Turkish Film Industry named Yeşilçam (Pinetree) ${ }^{13}$ arose an important film movement known as "Social Realism" (Toplumsal Gerçekçilik). Like the French Nouvelle Vague and the Brazilian Cinema Novo, Turkish Social Realism was also related to the legacy of Italian neo-realism whose leftward oriented politics and realist-minimalist aesthetics fitted well with the socio-political concerns of a new generation of Turkish filmmakers eager to develop a "national" film language. Until 1960, (the year of the Coup d'Etat) the Turkish commercial film industry known as Yeşilçam (Pinetree) had only produced

\footnotetext{
${ }^{6}$ Cesare Zavattini (1978). A Thesis on Neo-Realism. In Overbey (ed.), Springtime in Italy: A Reader on Neo-Realism. Connecticut: Archon Books, p.76.

7 Siegfried Kracauer (1960). Theory of Film. Oxford University Press.

8 Cesare Zavattini, A Thesis on Neo-Realism, p.71.

${ }_{9}^{9}$ Sadoul quoted in George Huaco (1965). The Sociology of Film Art. New-York: Basic Books, p.157.

${ }^{10}$ Bordé and Bouissy (1960).

${ }^{11}$ Amedée Ayfre (1964). Untitled. Etudes Cinématographiques. $32-35$ (Special issue on Italian Neo-Realism).

12 Ben Lawton (1979), p. 10.

${ }^{13}$ Yeşilçam (Pinetree) is the name given to Turkish film industry. Like its counterpart in India, it is famous (and also harshly criticized) for its melodramas and rather "primitive" filmmaking practices.
} 
commercial, "genre" films. After 1950, a young generation of filmmakers like Lutfi Akad and Metin Erksan started to get curious about "art cinema" and they wanted to develop a national film movement in Turkey following the model of Italian neo-realism . But due to the existing mechanisms of censure of the Democrat Party era, they had to wait until the "progressive" coup of the $27^{\text {th }}$ of May 1960 which brought some freedom to the country with the change of the Constitution and the implementation of certain welfare measures. Reminiscent of the Italian neo-realist movement whose political content could only become manifest as the "anti-fascist" Catholic-Communist Alliance was made (following the fall of Mussolini régime, the Italian Communists led by Togliatti and Christian Democrats headed by De Gasperi formed a political alliance that lasted until early 1948), Turkish social realism in film was directly linked to the overthrow of ruralliberal Adnan Menderes (leader of the Democrat Party that ruled the country for 10 years) by the military coup of May 1960, and the adoption of a new social democratic Constitution in 1961. As Halit Refiğ, one of the leading figures of the movement puts it:

\begin{abstract}
"...The Constitution of 1961, the newly founded political parties, and the elections created a suitable socio-political atmosphere for us to analyze from a different perspective the pressing problems of our country. The political activism that followed the May 27th coup d'Etat quickly spread to the realm of film. It created the necessary conditions for the birth of a film wave that is sometimes called "social realism", focusing on the structural problems of our country and analyzing human interactions within different social layers..."14
\end{abstract}

Thus between 1960 and 1965, a cinematic movement known as "Social Realism" developed in Turkey. The Films of Halit Refiğ, Metin Erksan (who won Golden Bear in Berlin with Susuz Yaz-Dry Summer in 1963), Ertem Göreç and Duygu Sağıroğlu were the best examples of this short lived movement. Like its Italian counterpart, the Turkish social realism in cinema was deeply embedded in politics. Particularly the Neo-Kemalist Yön movement and the formation of TiP (Turkish Labor Party) had great impacts on the filmmakers. The "progressivist" and "populist" tendencies of the post 1960 élite (also known as the "neo-Kemalists") were clearly present in the movement with an increased dose of universalism and class politics.

\title{
4. Yılmaz Güney
}

In the 1970s Yılmaz Güney (already known in the popular Yeşilçam film industry as the "ugly king of Turkish cinema")emerged as an "engagé" filmmaker and applied some of neo-realism's basic principles in his films (especially in Umut (Hope,1970) and Sürü (Herd, 1978). But Güney was much bitter in his social criticisms and favoured a more pronounced universal understanding of Marxism (in contrast to the "local", Kemalist leftism of the social realist filmmakers). His films were, thus, in many cases, closer to "socialist realism" than the "critical realism" of the neorealist tradition. As emphasized above, within neo-realism there were filmmakers closer to the notions of class politics as well as those favoring a more "humanistic" stress upon solidarity. In his earlier films such as Umut (Hope, 1970)Yılmaz Güney was, thus, more sympathetic towards the bitter agonies of the lower strata.

Born in 1937, Yılmaz Güney's real surname was Pütün. He was one of the seven children of a poor family of Kurdish descent living in Adana. So he was of Kurdish background but this did not occupy a central point in his political thinking as he had discovered "socialism" before Kurdish Nationalism. But there was always a reference to the harsh life conditions of Kurds as he knew from the lives of his mother and father. To reflect the Kurdish misery, he often focused on feudalism and patriarchal social order which is quite characteristic of Traditional Kurdish life. There was always a background criticism directed towards the official governmental policies towards the Kurds which pushed them towards smuggling or banditry. But this was nevertheless quite indirect as his analysis was often "class-based". So he was a socialist and we can see it in many forms in his films. But he also confessed in many times that he was not able to make films as exactly as he wished because of the pressures of state censorship. So he found alternative ways of expressing his thoughts. Roy Armes explains that instead of i.e. saying "organize yourselves" Güney would show the dead end of "individualism" (how bandits can never get organize and really change their lives as they are always mesmerized by false codes of heroism blood feuds and vendettas). ${ }^{15}$ This was quite similar to some of the neo-realist films which for political and social reasons refrained from making bold statements and preferred to show in a "popular as well as intellectual" manner the agonies of the poor.

${ }^{14}$ Halit Refiğ (1971). Ulusal Sinema Kavgası. Istanbul: Hareket Yayınları, p. 24.

${ }^{15}$ Roy Armes (1987). Third World Filmmaking and The West. University of California Press. 
Before he became an acknowledged intellectual filmmaker, Güney was a popular actor and director within Yeşilçam. Similar to Vittorio de Sica who had a considerable fame as a popular actor, Güney was the "ugly king of Turkish cinema". He was known within the "Social Realist" circles, but as his political engagements were deemed to be more dangerous by the political authorities, he was jailed in 1961 for communist propaganda. But this propaganda was not something found in his films which were, at that time, commercial Yeşilçam films. After he was released from prison he started to work with small production companies and created the myth of the "lumpen king". He became the king of the "periphery", of the Anatolian male migrants whose identity was in conflict with the "urban-middle class" identity propagated in many commercial films. In the early stage of his career, thus, we see that he was more conditioned by the audience and its expectations. It gradually started to change after 1965. Starting with Lutfi Akad's film Hudutların Kanunu (The Law of the Borders, 1966) he departed from the exaggerated melodramas of Yesilcam and brought a more balanced down to earth look on his characters. After 1970 we see a totally new Yılmaz Güney. Between 1970 and 1984 five of his films won international acclaim: The Hope (1970), The Friend (1974), The Herd (1978), The Road (awarded Golden Palm in 1982,), The Wall (1983). ${ }^{16}$

Umut (Hope, 1970) is YIlmaz Güney's first throughoutly artistic work and it also signals the birth of the so-called "new Turkish cinema" (which will become the motto of Nuri Bilge Ceylan's generation). Hope is also Güney's closest film to Italian neo-realism. In summary, it tells the story of an impoverished horse cart driver Cabbar (acted by Güney himself), who lives amidst poverty in Adana and ceaselessly dreams of a better life for his family. When he loses the horse because of a wealthy and careless driver, he falls into despair. Rejecting the invitation to join some of his fellow workers who plan for political action, Cabbar prefers to try his chances first in the lottery and then in rumors of a buried treasure. He cannot find the alleged buried treasure for which he abandoned his suffering family and the film's dark ending leaves no "hope" for the future.

The film has many points in common with the masterpieces of Italian neorealism. Firstly it tells the story of ordinary people portrayed in their real environment facing real problems. As emphasized by Zavattini in his thesis on NeoRealism, in Hope there are no extraordinary characters to identify with. The film is shot on location around Adana with the participation of local people. The plot is simple and although very rich in analytical layers it can be understood by a wide range of people. The plot also has some affinities with De Sica's Bicycle Thieves. Similar to Ricci who loses the bicycle and consequently falls into despair, Cabbar loses the horse and undergoes great hardships. The recourse to fortune tellers is also a background motif in Bicycle Thieves that has a much greater weight in Hope. The film is also reminiscent of Luchino Visconti's great epic La Terra Trema whose main protagonist Ntoni is condemned because of his individualistic fight against the wholesalers through the loans he gets from a bank. Cabbar's misfortune can also be partly understood in this vein. For Güney, instead of trying to get rich through irrational dreams, Cabbar should have joined his fellow workers. Although Hope gets darker and darker towards the end and diverges from neo-realist aesthetics which often leaves some optimism for the future, it can nevertheless be considered as the first example of a Turkish new realistic cinema.

\section{Nuri Bilge Ceylan}

One of the most outstanding filmmakers of the new Turkish Cinema who won an international acclaim through Cannes such as Güney, is Nuri Bilge Ceylan born in 1959. Contrary to Güney, Ceylan, had very personal choices and refrained from getting popular in the initial stages of his directing career. In his "Trilogy of Province" composed of Kasaba (The Small Town 1997), Mayıs Sıkıntısı (The Clouds of May, 1999) and Uzak (Distant, 2002) he preferred a "minimalistic" cinema reminiscent of Kiarostami and Ozu's existential humanism as well as neo-realism. Thus contrary to Güney's pronounced political tone, Ceylan borrowed neo-realism's phenomenological principles including minimalism, modesty and documentary verism.

Ceylan's childhood was spent in Canakkale Yenice where his father worked as an agricultural engineer after his degree from US (a much debated issue in The Small Town-is it rational to go back to his native village after a degree from the US?) His happy childhood in Yenice has been very important for Nuri Bilge Ceylan and he referred to it over and over in his Trilogy of Province. The beautiful landscapes and nature of Yenice and his nostalgia for his lost childhood are recurrent themes of his earlier films. From Small Town to Distant all his films are almost exact autobiographical replicas of his agony and pain from getting away from this harmonious life within nature. Ceylan's quest for this childhood innocence

\footnotetext{
${ }^{16}$ Atilla Dorsay (2004). Yılmaz Güney Kitabı. Istanbul: Güney Yayınları.
} 
was not limited to the plots of his films. Loathing all kinds of "fakeness", he refrained from engaging professional actors in his films. In his first trilogy he casted his real family (his mother, father, cousin, wife etc.) as the main protagonists of the films. He gave almost no press interviews until Distant's unexpected success at Cannes. As he did not want to burden himself with bureaucratic details, he did not apply for financial support from Ministry of Culture. So his initial films were made with unbelievably small budgets. Having a strong background in photography, he embraced the Kracauerian notion that "film is ontologically a continuation of photographic realism". ${ }^{17}$ So tightly rooted in daily existence, his initial films of Provincial Trilogy did not have developed plots but had basic themes enriched with stories found within simple details of everyday life. So in the Small Town, we are simply invited to feel and share the boredom of a young man who wants to leave his native village. We are also given the chance to contemplate the beautiful photographic details of life within this small town. In Clouds of May, Ceylan tells in a quasi ciné-verité fashion how he shot his previous film, the Small Town. The difficulties he had with his family while shooting the film, the impossibility of a healthy communication with the villagers and his father's deep passion for his land are the main themes of his second film. The harmony between man and nature plays a great part in Clouds of May contrary to Distant (the last film of the Trilogy) which reflects Ceylan's personal alienation within the big city and his total rupture from Yenice. In Distant set in Ceylan's own appartement at Cihangir Istanbul, two cousins, separated at the end of Clouds of May reunite, but this reunion turns into a power game between the hopeless young man from Yenice and his successful but unhappy elder cousin.

In all the three films comprising the "Trilogy of Province" Ceylan uses the same stylistic techniques reminiscent of neo-realism. Like Güney and the masters of neo-realism, he prefers nonprofessional actors and he tries to truthfully reflect the surrounding physical reality. But contrary to Güney who, nevertheless, wished to give a certain subjective political direction to the viewers, Ceylan was obsessed with "minimizing the lie of cinema"18. This wish to totally refrain from manipulating or deceiving the viewers pushed Ceylan to construct very minimal stories comparable to the innocent "slight dramas" of Abbas Kiarostami. As Ceylan also admits, for his "Trilogy of Province", the "slight narrative" cinemas of Yasujiro Ozu and Abbas Kiarostami were very important. Thus, until the making of Climates (2006) which signalled the end of Ceylan's "redemption of physical reality" Ceylan's cinematic universe included:

a. A deep passion for classic photography as the ontological source of realistic cinema. We do not know if Ceylan was familiar with the work of Siegfried Kracauer, but his earlier films were good examples of Kracauerian notion of cinema as the "physical redemption of reality". Kracauer, a prolific German writer and philosopher, had written in the 1950s that, as exemplified in many neorealistic films and also praised (with a somewhat different emphasis) by the French critic André Bazin, the "true" cinematic film should have a simple story, not overwhelming the visualization of physical reality. This story should have "permeability" which leaves room for spontaneity and continuity (the story should not "end"). It should be based on th earth (material existence) and the ordinary details of simple people. ${ }^{19}$ This is also a "contemplative cinema" in Dabashi's words, which reveals the "beauty in the benign brutality of being". ${ }^{20}$

b. A political tone in an apolitical guise. Contrary to Güney, or some neo-realist filmmakers such as Visconti or De Santis, Ceylan hardly talks about anything political. But by rejecting the present culture of consumption and excess through humble and slowly proceeding silent stories, by painfully trying to avoid the lie of cinema through minimal editing, sound, camera jobs and acting, by radically challenging the established norms of popular cinema through totally personal works, Ceylan is political in his first films, if not with "what" he says, but with "how" he says.

c. A background individualism and pessimism later to develop into total rupture from social action. Even in his earlier films praising harmony, nature and modesty, Ceylan is pessimistic about the possibility of true human solidarity. Compared to Kiarostami or the masters of neo-realism, his characters are generally lazy and more selfish. The degree of this selfishness increases dramatically from The Small Town to Distant, and the former's rather humorous small human defects turn into variations of sadism in the latter. And from Climates onwards, Ceylan is carried away into new modes of nihilism which estrange him further from this childhood innocence he was once desperate to catch in cinema.

\footnotetext{
17 Siegfried Kracauer (1960).

${ }^{18}$ Fatih Özgüven (2003). Nuri Bilge Ceylan ile Kişisel Yolculuk. Yirmibir Mimarlık Dergisi, May, p.12.

${ }^{19}$ Kracauer (1960).

${ }^{20}$ Hamid Dabashi (2001). Close Up Iranian Cinema. London: Verso.
} 